\title{
El futuro se repite: priming effects in Spanish future expressions
}

\author{
Luana LAMBERTI (1) \\ The Ohio State University (OSU) \\ Hugo SALGADO 『 \\ The Ohio State University (OSU)
}

\section{OPEN ACCESS \\ EDITED BY \\ - Raquel Freitag (UFS) \\ REVIEWED BY \\ - Marcus Maia (UFRJ) \\ - Mahayana Cristina Godoy (UFRN) \\ ABOUT THE AUTHORS \\ - Luana Lamberti \\ Conceptualization, Data \\ curation, Formal analysis, \\ Methodology, Visualization, \\ Writing - original draft - and \\ Writing - review and editing \\ - Hugo Salgado \\ Conceptualization, Data \\ curation, Formal analysis, \\ Methodology and Writing - \\ original draft.}

DATES

- Received: 15/10/2020

- Accepted: 14/01/2021

- Published: 26/01/2021

HOW TO CITE

Lamberti, L.; Salgado, H. (2020). El futuro se repite: priming effects in Spanish future expressions. Revista da Abralin, v. 19, n. 1, p. 1-18, 2020.

\section{ABSTRACT}

Spanish shows variation between two future expressions. The synthetic future $(\mathrm{SF})$ is marked morphologically while the periphrastic future $(\mathrm{PF})$ is constructed with the verb ir 'to go' and an infinitive. Previous studies have described the semantic factors that determine the use of these expressions. The effects of priming in the selection of these expressions have yet to be addressed. Our results showed that a combination of factors contributes to the occurrence of the SF: priming effect; certainty; and verb frequency. We demonstrated that cognitive factors in combination with semantic ones should be taken into consideration when talking about the variation between the SF and the PF in Spanish. Our study also provides evidence for the fact that the obsolescing construction, the SF, will have a stronger priming effect in the larger process of language variation and change. Our work offers an important addition to the literature about the effects of persistence and entrenchment in language since we demonstrated that speakers are sensitive to contextual activation and language use factors.

\section{RESUMO}

A língua espanhola mostra variação entre duas expressões futuras. O futuro sintético (FS) é marcado morfologicamente enquanto o futuro perifrástico (FP) é construído com o verbo ir 'ir' e um infinitivo. Estudos anteriores descreveram os fatores semânticos que determinam o uso dessas expressões. Os efeitos de priming na seleção destas expressões ainda precisam ser abordados. Nossos resultados mostraram que uma combinação 


\section{REVISTA DA ABRALIN}

de fatores contribui para a ocorrência do FS: efeito priming; certeza do evento; e frequência do verbo. Demonstramos que fatores cognitivos em combinação com semânticos devem ser levados em consideração ao falar sobre a variação entre o FS e o FP em espanhol. Nosso estudo também fornece evidências para o fato de que a construção obsoleta, o futuro sintético, terá um efeito de priming mais forte no processo de variação e mudança deste fenômeno. Nosso trabalho oferece um acréscimo importante à literatura sobre os efeitos da persistência e do entrincheiramento na língua, uma vez que demonstramos que os falantes são sensíveis à ativação contextual e aos fatores de uso da língua.

\section{KEYWORDS}

Spanish. Future. Variation. Priming effect.

PALAVRAS-CHAVE

Espanhol. Futuro. Variação. Efeito de priming.

\section{Introduction}

Spanish shows variation between two future expressions. ${ }^{1}$ The Synthetic Future (SF) is marked morphologically, as seen in (1a), while the Periphrastic Future (PF) is constructed with the verb ir 'to go' plus an infinitive, as in (1b).

(1) a. come-ré pizza mañana eat-1sg.fut pizza tomorrow

b. voy a com-er pizza mañana

go to eat-inf pizza tomorrow

'I will eat pizza tomorrow'

While several factors that seem to determine the use of these expressions have been proposed and thoroughly analyzed in the literature, the effects of priming on their selection are yet to be addressed. This paper contributes to the literature on Spanish future expressions by assessing the role of priming on the choice of the SF and PF in two oral corpora of South American and Peninsular

\footnotetext{
${ }^{1}$ Even though futurity in Spanish can be expressed through several forms, such as the Futurate Present or other modal constructions, this paper is only concerned with the variation between the Synthetic and Periphrastic futures, the so-called "morphosyntactic futures" (AARON, 2014).
} 


\section{REVISTA DA ABRALIN}

Spanish: Macro-corpus de la norma lingüistica culta de las principales ciudades del mundo hispánico (henceforth MCN) (SAMPER; HERNÁNDEZ CABRERA; TROYA, 1998) and La lengua hablada en Alcalá de Henares: Corpus PRESEEA- Alcalá (ALC) (MORENO FERNÁNDEZ; CESTERO MANCERA; MOLINA MARTOS; PAREDES GARCÍA, 2002).

The structure of this work is as follows. In $§ 1$, we summarize the factors that have been recognized in the literature as the most important in the selection of the future expressions of interest. We also provide a brief account of priming and its role in the conservation of less frequent linguistic variants as well as the research questions. The methodology follows in $\S 2$ and the results are presented in $\S 3$. In $\S 4$ and $\S 5$, we present the discussion and the general conclusions of this study.

\section{Background}

\subsection{Factors governing the choice of Spanish future expressions}

The forms of the Spanish futures can express a diversity of meanings other than futurity per se (AARON, 2014; FERNÁNDEZ RAMÍREZ, 1940). For example, the form of the SF can be used to convey events that are seen as hypothetical by the speaker, a use known as the epistemic future (AARON, 2014), illustrated in (2a). Here, by using the SF form será, the speaker is not conveying that the job discussed in the previous context will be difficult, but rather that he believes it is difficult. Differently, the form of the PF is used to express motion towards some goal (SEDANO, 1994) and not futurity. In (2b), for example, the speaker conveys that he goes to Madrid to study, not that he will study in Madrid.

(2) a. trabaja de poner una consulta y esperar, me imagino que se-rá bastante he.works in building a clinic and wait, myself I.imagine that to.be-3sG-Fut quite dificultoso

difficult

'He works in building a clinic and waits, I imagine it is quite difficult' (MCNMA04)

b. los sábados voy a estudi-ar en Madrid the Saturdays I.go to study.INF to Madrid

'On Saturdays, I go to study to Madrid' (MCN-MA05)

The present research, however, is concerned only with future expression forms conveying actual future-time reference. In this respect, a number of factors have been proposed in the literature as governing the use of future expression in Spanish. For instance, the temporal distance of the future 


\section{REVISTA DA ABRALIN}

action in relation to the present has been numerously cited as one of its most important determinants (SEDANO, 1994; FLEISCHMAN, 1982). Accordingly, more immediate future events prefer the PF while events more distant in time prefer the SF (BLAS ARROYO, 2008).

Additionally, governing factors of a more psychological nature have been proposed, as is the case of certainty (AARON, 2014; ALMEIDA; DÍAZ, 1998), also known as confidence in some works (e.g., BLAS ARROYO, 2008). Although there seems to be no consensus in the literature as to the definition of this factor, for the purposes of this research, we follow Almeida and Díaz's (1998) definition of certainty as "the different certainty degree of the future event". As reported by these studies, the PF is preferred for future actions which, according to the speaker, will unfold with certainty. In contrast, the SF is used for actions whose outcome is shrouded in uncertainty (AARON, 2014; BLAS ARROYO, 2008).

While other potential linguistic factors that could affect the variation at hand have been proposed as well, such as style, temporal determinacy, and connection of the future event with the present of the speaker, they have found less support among scholars. For this reason, in this paper we focus on the two semantic factors that have been shown to be most relevant, namely temporal distance and certainty.

Importantly, despite the picture of complementary distribution in future expressions that the past characterizations may suggest, previous studies find that their distribution is by no means clear-cut. In fact, variation is found even in contexts that have been identified as highly preferring one form. Consequently, the selection of future expressions in Spanish has been described as lying between complementary distribution and "free variation", suggesting that speakers have more choice in certain contexts than in others (AARON, 2014; BLAS ARROYO, 2008).

Finally, in addition to these linguistic factors, the preference for one or the other future expression is also subject to dialect-specific tendencies. Sedano's (2006) survey of seven spoken Spanish varieties finds that, in general, the SF is the least frequent future expression, an observation that had been made in previous impressionistic studies (KANY, 1945). Furthermore, this author identifies differences in the overall frequency of the SF in these varieties along a continuum of use. In one extreme, the SF is more frequent in Spain $(40 \% 1352 / 3380)$ and in Mexico (31\% 374/1198). In the other, the Spanish of Dominican Republic (0\% 0/16) and Chile (2\% 1/65) show the lowest usage rates of the $\mathrm{SF}$, admittedly with a very small sample. Intermediate rates of use are found among the South American dialects. These tendencies of use are illustrated in Figure 1.

\footnotetext{
${ }^{2}$ No original: "el diferente grado de certidumbre sobre el cumplimiento de la acción futura".
} 


\section{REVISTA DA ABRALIN}

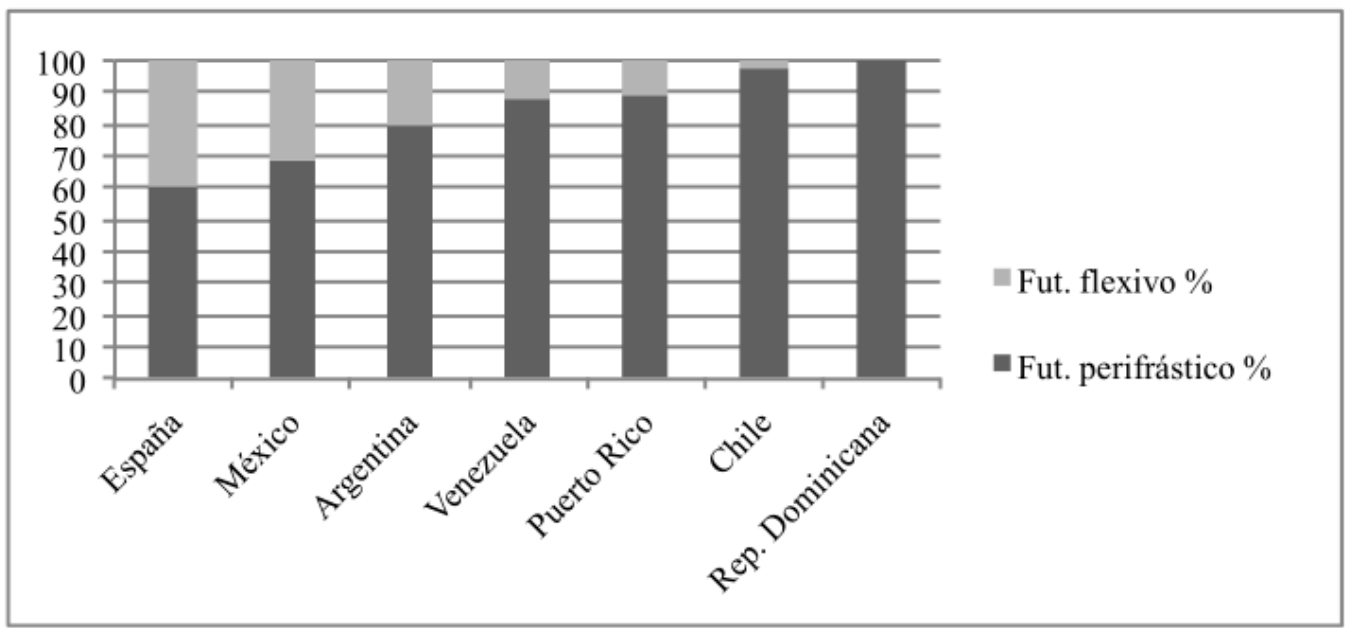

FIGURE 1 - Percentage of use of each future expression per country

Source: Sedano (2006, p.284)

\subsection{Priming and entrenchment}

A great wealth of evidence from psychology, psycholinguistics, and linguistics shows that speakers are more likely to use a syntactic construction that they have used or heard in the previous context - a phenomenon known priming or persistence (SZMRECSANYI, 2005). In a classic study about retrieval of words, Meyer and Schvaneveldt (1971) using perception experiments, demonstrated that our memory is organized by familiarity as well as by meaning "with frequently examined locations in one "sector" and infrequently examined locations in another sector" (MEYER; SCHVANEVELDT, 1971, p.232). For instance, Szmrecsanyi (2005) found that English speakers are more likely to use gonna rather than will when there is a previous gonna in the discourse. For Spanish, Rosemeyer's (2015) diachronic study describes that the archaic perfects with ser, such as soy venido 'I have come', are more likely when another ser-perfect is found in the previous discourse. An even more interesting finding from previous studies on priming is that linguistic variants with lower frequency seem to have stronger priming effects. This is illustrated in Rosemeyer and Schwenter's (2019) diachronic study on the alternation of Spanish past subjunctives with -ra, as in pudie-ras 'can-2sg.past.subj', and subjunctives with -se, as in pudie-ses 'can-2sg.past.subj'. The authors find that subjunctives with -se are by far the least frequent in the surveyed texts and document a diachronic pattern of replacement that led -ra subjunctives to become the dominating variant. However, consistently across temporal stages, when there is a previous -se subjunctive in the discourse, speakers are more likely to use another -se subjunctive rather than a -ra subjunctive.

In turn, this finding has implications for language change. The authors find that -se subjunctives are mostly restricted to high-frequency verbs, such as ser 'to be', estar 'to be', and haber 'to have'. The 


\section{REVISTA DA ABRALIN}

explanation for the conservation of the -se subjunctives with these verbs is to be found in entrenchment (LANGACKER, 1987, p.59). In other words, these high- frequency linguistic items are stored as a whole "chunk" in the speakers' minds and are no longer analyzable in their component parts. Since the entrenched items are interpreted and processed as a different pattern, they are less subject to replacement by other linguistic variants - the -ra subjunctives in this case. Entrenchment in turn led to the paradigmatic atrophy (LEECH; HUNDT; MAIR; SMITH, 2009, p.80) of the -se subjunctives, that is, their reduced productivity relegated to a small number of verbs.

However, Rosemeyer and Schwenter (2019) show that primed -se subjunctives occur in fact with a larger inventory of verbs than unprimed -se subjunctives. The interpretation of this seemingly reviving effect of a previous -se subjunctive is that priming activates the construction with -se in the speaker's mind, therefore allowing her to use it with a larger range of verbs than when unprimed. Thus, the authors conclude that priming can act as a conserving force in language change as a sort of counterbalance to paradigmatic atrophy.

In sum, the literature identifies several semantic factors that could affect the selection of future expressions in Spanish, such as temporal distance and certainty. However, it is also subject to extralinguistic factors, especially dialect-specific preferences. While the SF is the least frequent future expression in all Spanish speaking countries, it is relatively more common in Spain. Other Spanishspeaking regions such as South America show lower rates of use of the SF. Finally, priming is another factor that can affect the use of linguistic variants. Previous studies show that its effects are stronger among less-frequent variants and that it can have a conserving effect in language change.

\subsection{Research questions}

Informed by the studies described in the previous subsections, we propose the following research questions:

1. What effect does priming have on each Spanish future expression ( $\mathrm{PF}$ and $\mathrm{SF}$ )?

2. What are the differences in priming effects on future expressions according to geographical region (South America vs Spain)?

These questions, in turn, have their corresponding hypotheses:

H1: a SF will be more likely after a previous SF in the discourse because it is the least frequent variant.

H2: there will be stronger priming effects of the SF in South American than in Peninsular Spanish because the SF is less frequent in South America. 


\section{Methodology}

As mentioned in the introduction, we looked for future expressions in two oral corpora of Spanish from Spain and South America. In total, we analyzed 82 interviews from tree cities in Spain - Madrid, Alcalá de Henares, and Seville - and three cities in South America - Buenos Aires (Agentina), La Paz (Bolivia) y Caracas (Venezuela). The key terms used for the searches in the corpora are shown in Table 1. We considered only future expression forms that had unambiguous future reference.

\begin{tabular}{l|l} 
Search terms for the SF & Search terms for the PF \\
\hline \hline ré, rás, rá, remos, réis, & $\begin{array}{l}\text { voy a, vas a, va a, vamos } \\
\text { rán vais a, van a }\end{array}$
\end{tabular}

\section{TABLE 1 - Key terms used for corpus searches}

Priming was captured using the factor recent. This factor records the type of the first future expression within the 150 words before the token and has the levels synthetic (if the previous future was a SF), periphrastic (if the previous future was a PF) and nothing (if there were no previous futures). For example, in (3), the first PF token voy a practicar 'I will practice' was coded as nothing because there were no future expressions in the previous 150 words. In contrast, the second PF me voy a dedicar 'I will dedicate myself' was accordingly coded as periphrastic given the presence of a previous $\mathrm{PF}$ and is considered a case of priming.

(3) entonces voy a practicar más y me voy a dedicar a todo eso

then I.go to practice more and myself I.go to dedicate to all that

'Then I will practice more and I will dedicate myself to all that' (MCN-LP9)

In addition, each token was manually coded for the semantic factors temporal distance and certainty. The temporal distance factor has the levels nondistant and distant. A token was coded as nondistant if the future action was to take place in the day of the utterance. In (4a), the interviewer asks about the interviewee's plans for that evening and his answer using a SF was coded as nondistant. In contrast, in (4b), the SF refers to next summer and was accordingly coded as distant.

(4) a. $y$ después, creo que $i$-remos al cine

And afterwards, I.think that go-1PL.FuT to.the movies

'And afterwards, I think that we will go to the movies' (MCN-MA03)

b. yo creo que en verano se puede... se pond-rá más de actualidad

I believe that in Summer itself can... itself can-3SG.FuT more of hip

'I believe that it will get more hip in the summer' (MCN-SE07) 


\section{REVISTA DA ABRALIN}

The certainty factor has the levels certain and uncertain. Following the definition of certainty by Almeida and Díaz (1998) in $\$ 1.1$, a token was coded as certain if there were contextual cues revealing the speaker's certainty about the unfolding of the future event. In (5a), the speaker is certain about the fact that she will not to go the event on August $15^{\text {th }}$. On the other hand, in $(5 \mathrm{~b})$, the speaker conveys uncertainty as to whether she will write nine or ten poetry books in the future.

(5) a. este año no voy a ir porque el quince de agosto es sábado this year not I.go to go because the fifteen of August it.is Saturday 'I will not go this year because the fifteenth of August falls on a Saturday' (ALC-03)

b. yo misma desconozco si me voy a quedar en los nueve o diez libros de I myself do.not.know whether myself I.go to stay in the nine or ten books of poesía poetry 'I myself don't know whether I will end up with nine or 10 poetry books' (MCN-SE07)

Finally, we coded for the frequency of the lexical verbs in the future expressions. This factor has two categories established according to the rank frequency of the verbs in Davies (2006): highfreq (if the verb rank frequency was below 500) and lowfreq (if the rank frequency was above 500). All other factors that we coded for and their respective levels are summarized in Table $2^{3}$.

\begin{tabular}{|c|c|}
\hline Factor & Levels \\
\hline Age & younger ( $23-35$ years), mid (36-59 years), older (more than 60 years) \\
\hline Sex & male, female \\
\hline Region & South America, Spain \\
\hline Person & $1,2,3$ \\
\hline Number & $\mathrm{S}, \mathrm{P}$ \\
\hline
\end{tabular}




\section{Descriptive results}

In this section we will provide the descriptive results of the variation between the PF and SF in Spain and South America. In §3.1, we present the results from both regions combined, while $\S 3.2$ and $\S 3.3$ respectively show the results for South America and Spain.

\subsection{Spain and South America}

In total, we collected 679 tokens of future forms bearing future reference meanings. Overall, we find that the PF is the most frequent future expression - a finding that agrees with the previous literature on this alternation (e.g SEDANO, 2006). This is illustrated in Figure 2.

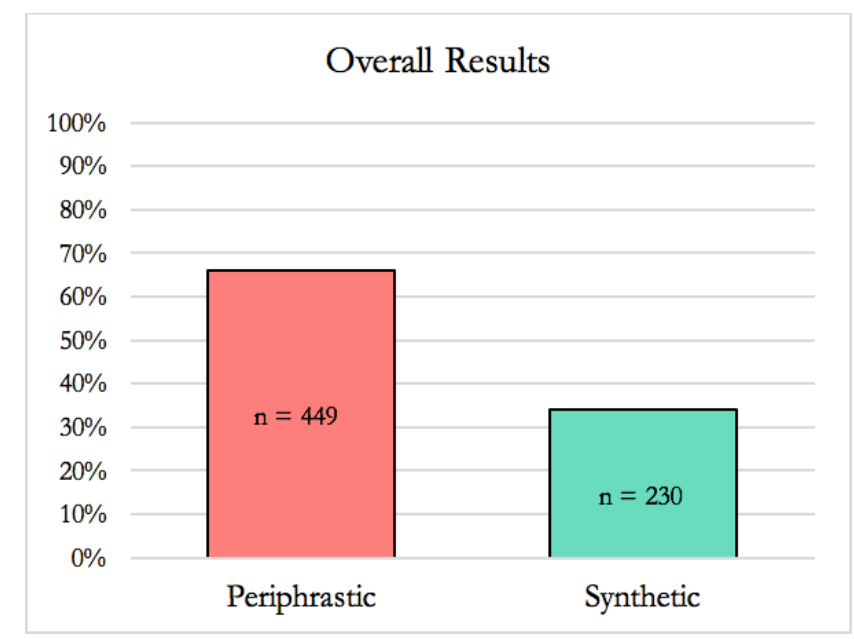

FIGURE 2 - Overall results

These percentages suggest that there is a change in the SF to the PF future form in the Spanish speaking world. We also ran a series of statistics analysis including data from both regions. These results were obtained through a mixed-effects logistic regression in R studio including speaker as a random effect. The significant factors were identified using the step function and then via random forests. Conditional Inference Trees were created to reveal interactions between significant independent variables. In total, we ran mixed-effects logistic regressions in three different sets of data: both regions, Spain only, and South America only. These results were later submitted to ANOVA summaries to select the models with the highest predictive power. Figure 3 shows the results of the best logistic regression model with data from both regions. 


\begin{tabular}{|c|c|c|c|c|}
\hline \multicolumn{5}{|l|}{ Coefficients: } \\
\hline & Estimate & Std. Error & $z$ value $\operatorname{Pr}(>|z|)$ & \\
\hline (Intercept) & -1.2711 & 0.1818 & $-6.9902 .74 e-12$ & $* * *$ \\
\hline recentperiphrastic & -0.7141 & 0.2178 & -3.2790 .001043 & $* *$ \\
\hline recentsynthetic & 1.8476 & 0.2512 & $7.3541 .92 \mathrm{e}-13$ & $* * *$ \\
\hline freq_catlowfreq & -1.5290 & 0.4043 & -3.7820 .000155 & $* * *$ \\
\hline regionSpain & 0.9094 & 0.1965 & $4.6283 .70 \mathrm{e}-06$ & $* * *$ \\
\hline Signif. codes: 0 & $* * 0$ & 01 “**, 0.01 & ‘*, 0.05 ' .0 . & ‘ ' 1 \\
\hline
\end{tabular}

FIGURE 3 - Mixed-effects logistic regression results for Spain and South America combined

In this model, positive estimates mean that the factor favors the use of the SF while negative estimates mean that the factor disfavors the SF. Figure 3 shows that a recent PF significantly disfavors the occurrence of a SF (nothing as intercept). In the same way, a recent SF significantly favors the use of another SF. Another variable that was selected as significant was frequency, which indicates that low frequency verbs disfavor the occurrence of the SF (highfreq as intercept). Finally, these results also provide evidence that speakers from Spain favor the use of the SF in comparison with South American speakers (South America as intercept). Figure 4 illustrates the raw token counts of each future type by region.

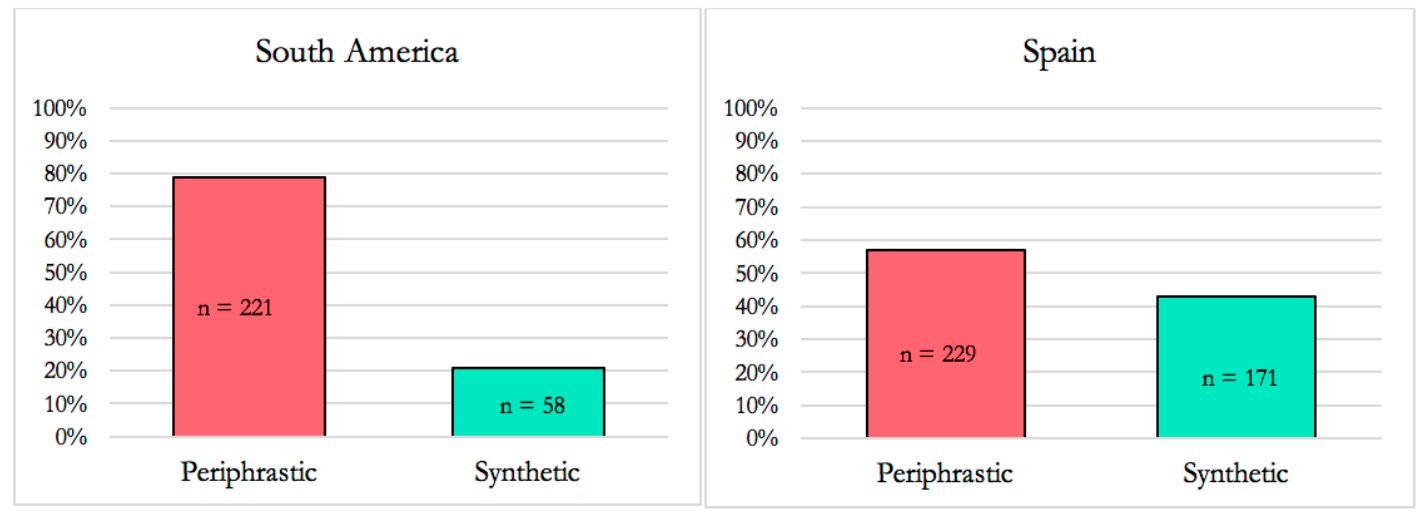

FIGURE 4 - Percentages of future expressions for South America and Spain

\subsection{South America}

We look now at the two different regions individually to understand what factors are con- tributing to the variation between the two future forms. In the South American Spanish varieties, as seen in figure 4 , there is a lower rate of use of the SF in comparison to Spain. The logistic regression analyses for each region were done following the steps detailed in the previous section. Figure 5 contains the significant factors that rule the variation between the two future forms in South America. 


\section{REVISTA DA ABRALIN}

As can be seen, the results of the best regression model for South America yielded very similar results to those in figure 3 , showing again that the factor recent is the most significant in determining the use of the future expressions. As was the case for both regions combined, in South America, a recent SF favors the occurrence of another SF, while a recent PF disfavors it (nothing as intercept). Additionally, the factor certainty was also selected as significant in this analysis, meaning that uncertain contexts favor the use of the SF in South America (certain as intercept).

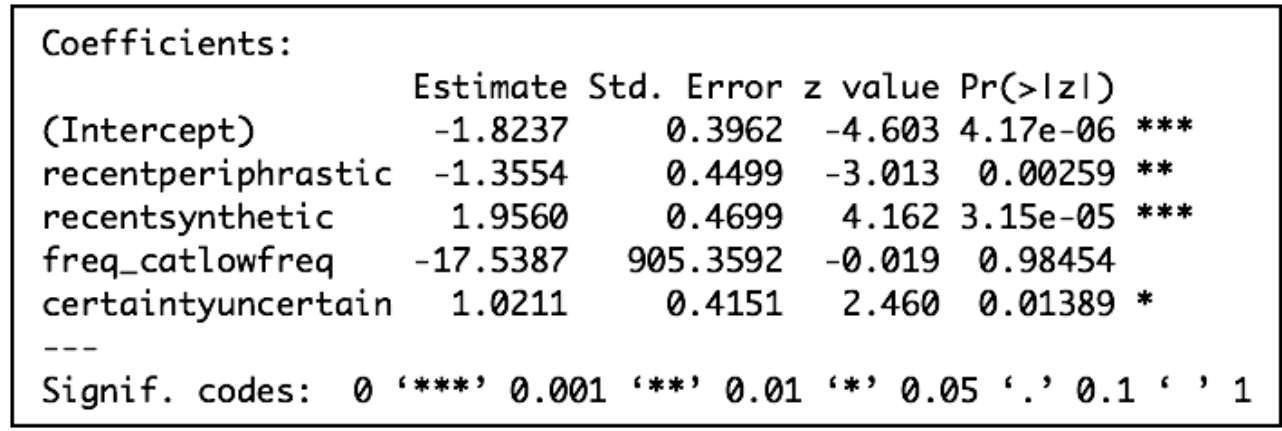

Recall that, as seen in figure 4, Spain presented higher rates of the SF in comparison to South America. The results of the logistic regression for Spain can be seen in figure 6 .

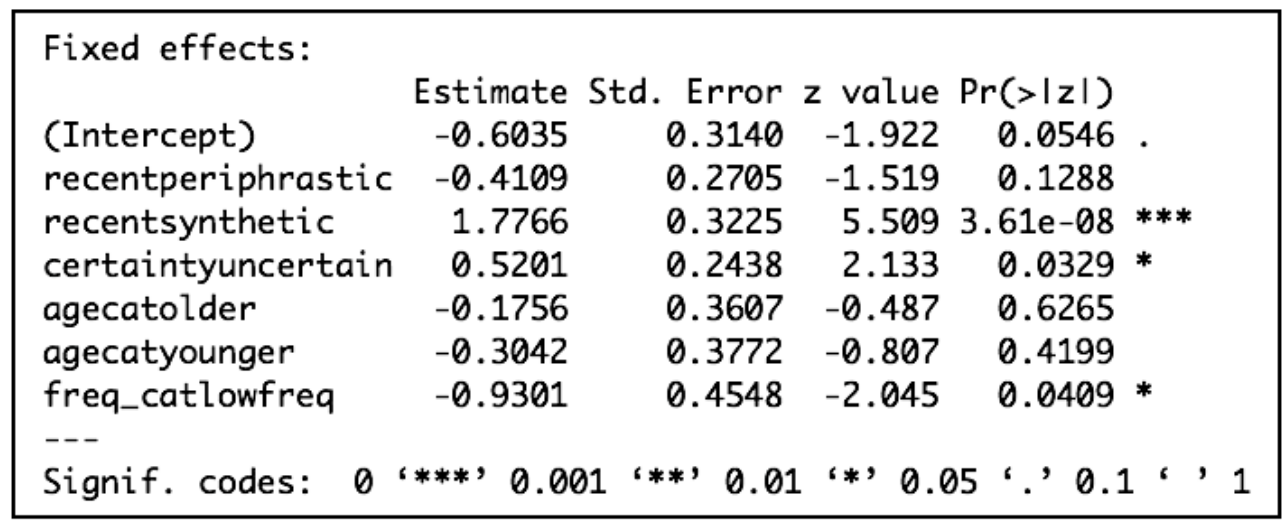

Here, we see again that the factor recent was selected as significant for explaining the variation between the SF and the PF-the positive estimate means that a recent SF favors the use of another 


\section{REVISTA DA ABRALIN}

SF in the discourse (nothing as intercept). Nevertheless, unlike the data from South America, a previous PF does not significantly disfavor a following SF, suggesting that a SF in Spain does not need to be primed in order to occur.

Moreover, similarly to South America, certainty was also selected as a significant factor for the variation, suggesting that the SF is favored in uncertain contexts (certain as intercept). Finally, figure 6 also shows that low frequency verbs significantly disfavor the occurrence of a SF in Spain.

\section{Discussion}

\subsection{Discussion: hypotheses revisited}

This study was set out to assess the importance of the priming effects in the occurrence of the Spanish future expressions. Our first hypothesis was the following:

H1: a synthetic future will be more likely after a previous synthetic future in the discourse because it is the least frequent variant.

This hypothesis was confirmed based on two main findings: first, we reported that the synthetic form is the least frequent variant in both dialects we studied (see figure 4). Second, we showed that a $\mathrm{SF}$ is more likely to surface after a recent SF in both regions. This was confirmed by the logistic regressions, which showed that the linguistic factor recent is significant to the use of a SF (see figures 5 and 6) in both regions.

Regarding the priming effect results, morphosyntactic priming has been shown to have an impact on language change in previous studies (ROSEMEYER, 2015; ROSEMEYER; SCHWENTER, 2019). Forms that have lower frequency of use in the language tend to present higher priming effects in comparison to forms with higher frequency. Rosemeyer and Schwenter (2019) define persistence as a strategy through which speakers are more likely to use an expression that has been used in the previous context.

As previously explained, we captured this definition in the analysis by coding for the independent variable recent, accounting for the most recent future form in the discourse. The results of this study demonstrated that in all regression models the recent factor was significant in ruling the variation between the SF and PF. These results are in line with the literature on the topic of usagebased linguistics, which holds that cognitive mechanisms are at the core of language variation and change. The raw counts in figure 7 summarizes these findings: 


\section{REVISTA DA ABRALIN}

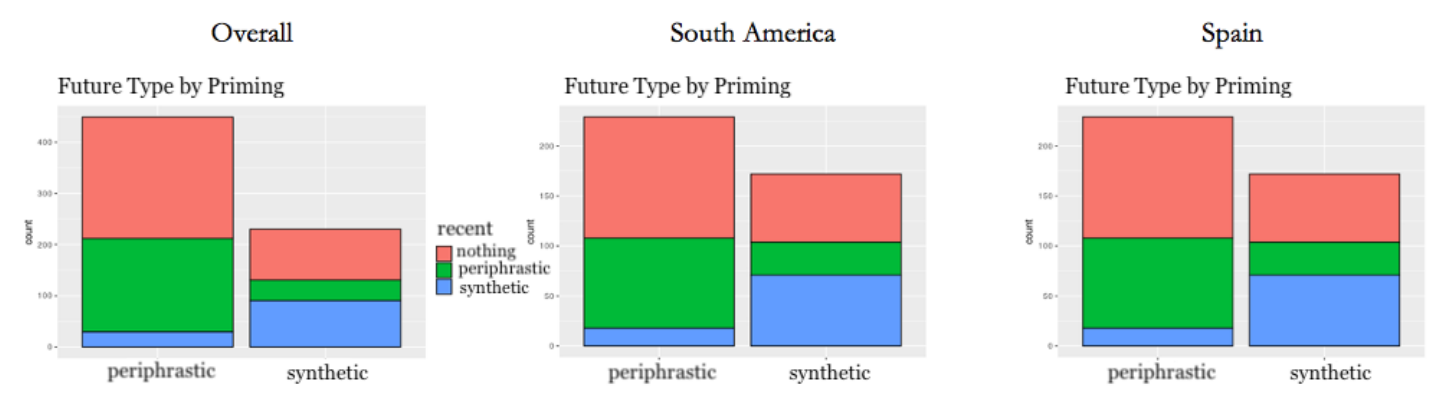

FIGURE 7 - Future type by priming in all models

The blue color in the graphs represents a recent SF. The priming effect can be observed in all three models. Rosemeyer and Schwenter (2019) posit that priming has an active conserving effect in language change. This statement is relevant for the interpretation of our results because we reported the importance of priming on the use of the SF (the least frequent form) which can be causing its conserving effect as a consequence. The authors also talk about the counterbalance between priming effects and paradigmatic atrophy, in which the entrenched elements are invariable in their form (occurring more often with the same verb frequency, number, and person). The current study also found the effect of paradigmatic atrophy in the SF - the SF occurs mostly with highly frequent verbs. Figure 8 includes the most frequent verbs in our data, and we can observe that the SF occurs with all of them:

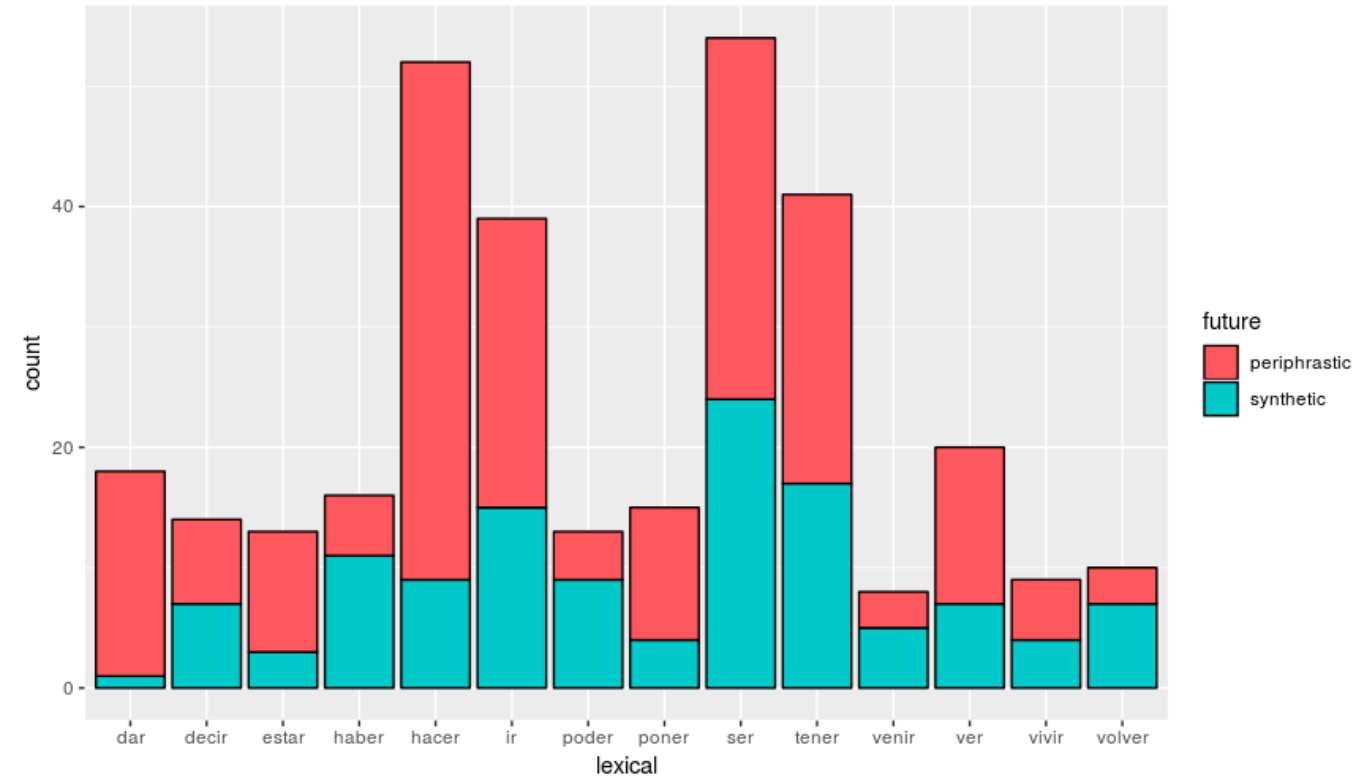

FIGURE 8 - Future type by lexical verbs 


\section{REVISTA DA ABRALIN}

As seen in the results from Spain and both regions combined, low frequency verbs disfavored the occurrence of a SF. In South America verb frequency was not significant because virtually there were no low frequency verbs with the SF as can be observed in figure 9 .

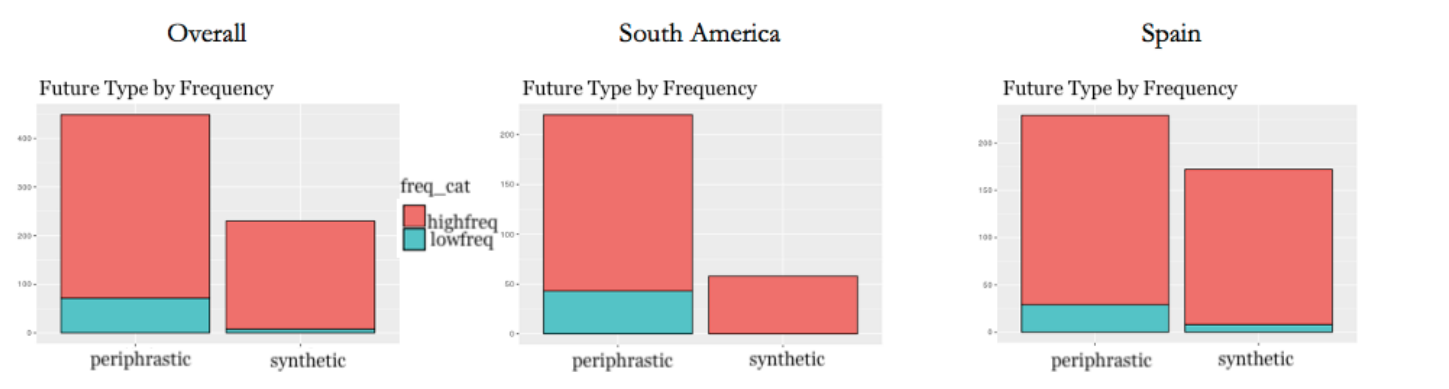

FIGURE 9 - Future type by verb frequency in all models

Still concerning the effect of paradigmatic atrophy, even though person and number were not select as significant linguistic factors in the logistic regression, the following graphs in figure 10 demonstrate that the SF occur mostly with 3rd person singular verb forms in Spain and South America, similar to Rosemeyer and Schwenter's (2019) results for the Spanish past subjunctive.

Now moving on to our second hypothesis that says:

H2: there will be stronger priming effects of the SF in South American than in Peninsular Spanish because the SF is less frequent in South America.

Our results showed priming effects in both regions, however, regarding the effect of paradigmatic atrophy we noticed that, in Spain, Spain, the SF is less contextually restricted in comparison to the data from South America. Figure 10 shows that a greater portion of the SF data appears with $1^{\text {st }}$ person in comparison to the South American results. 


\section{REVISTA DA ABRALIN}
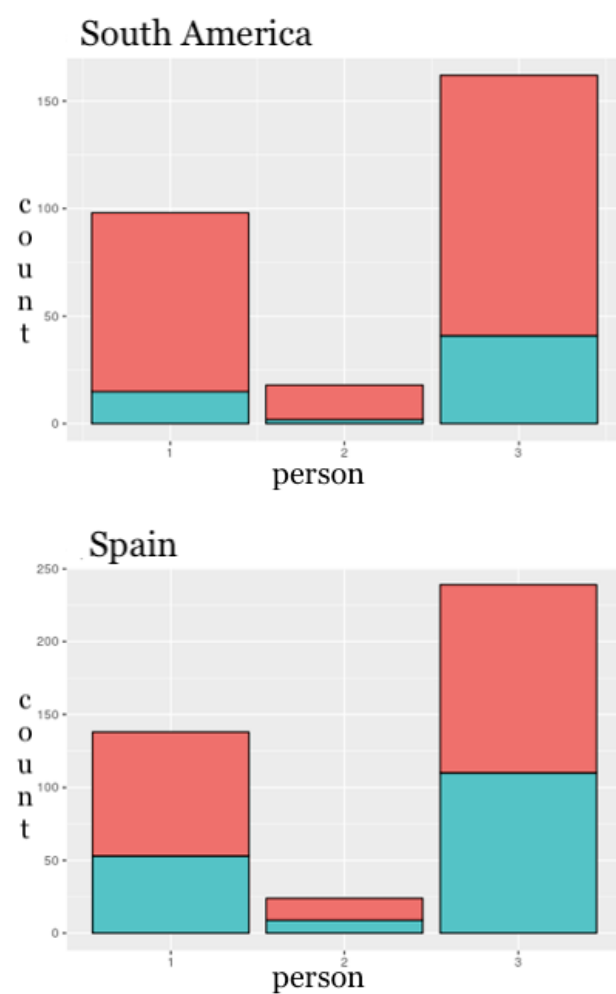
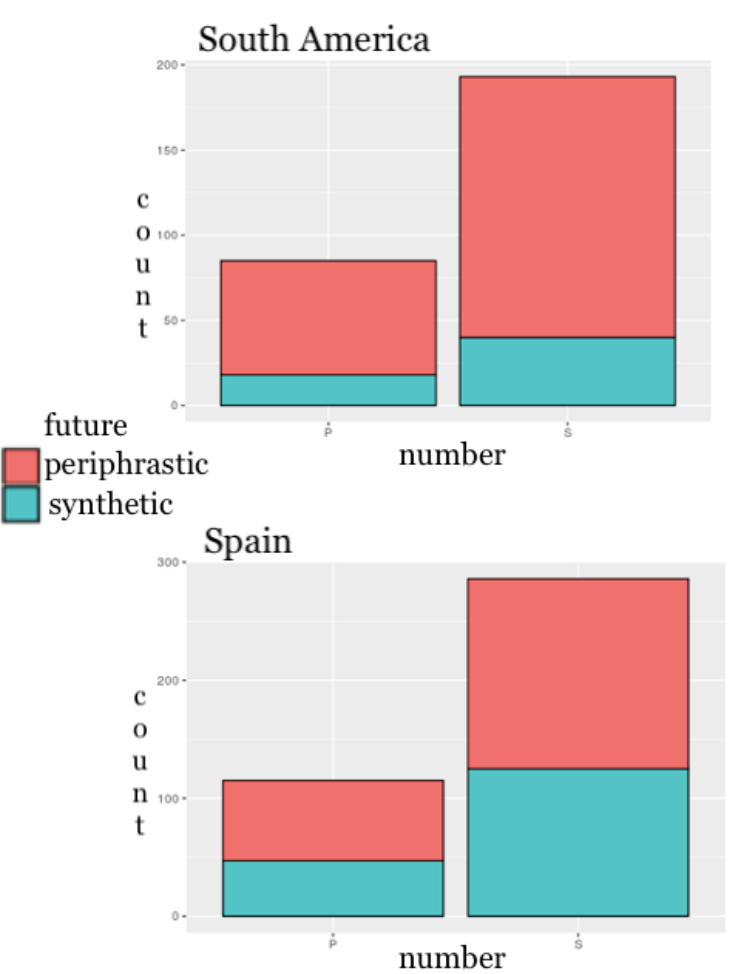

Regarding the number factor in Spain, there is a larger number of verbs in the SF that occur in the plural form in comparison to South America. It is important to note that this interpretation is based on token counts and not in statistical significance terms. However, we consider them to be illuminating in relation to the idea of paradigmatic atrophy and we would need more data in the future to support the idea about strictness of the context regarding person and number differences between Spain and South America.

Finally, commenting on the last factor that showed up as significant in our statistical analysis, we found that certainty regulates the variation between the two future forms investigated. Figures 5 and 6 show that uncertain contexts favor the use of the SF in both regions. These results confirm what was previously found in other studies (AARON, 2014; ALMEIDA; DÍAZ, 1998). Certainty is considered a psychological factor that is linked to the level of certainty (regarding speakers' expectations about the event) about the fulfillment of a given action in the future. Paradigmatic atrophy comes into play to explain these results as well. This is due to fact that the SF is becoming more and more specialized in regarding to its context of use. The combination of all the factors as frequency, person, number, persistence effect, and finally certainty constitute the prototypical context in which the least frequent future form (the SF) can be used by Spanish speakers. Again, they all contribute to the conserving effect of the SF in both varieties studied. In conclusion, Figure 11 shows the correlation between all the significant factors represented by an Inference Tree with data from both regions 


\section{REVISTA DA ABRALIN}

combined, and we can observe that, most importantly, if there was a recent SF that occurred in a uncertain context, there is a high chance that the next future form will be a SF. Spain, in general, also presents higher uses of the synthetic form. In the branch with the South American results, we observe that in the contexts where there was no previous future form with high frequency verbs, there is also a higher chance that the SF will surface.

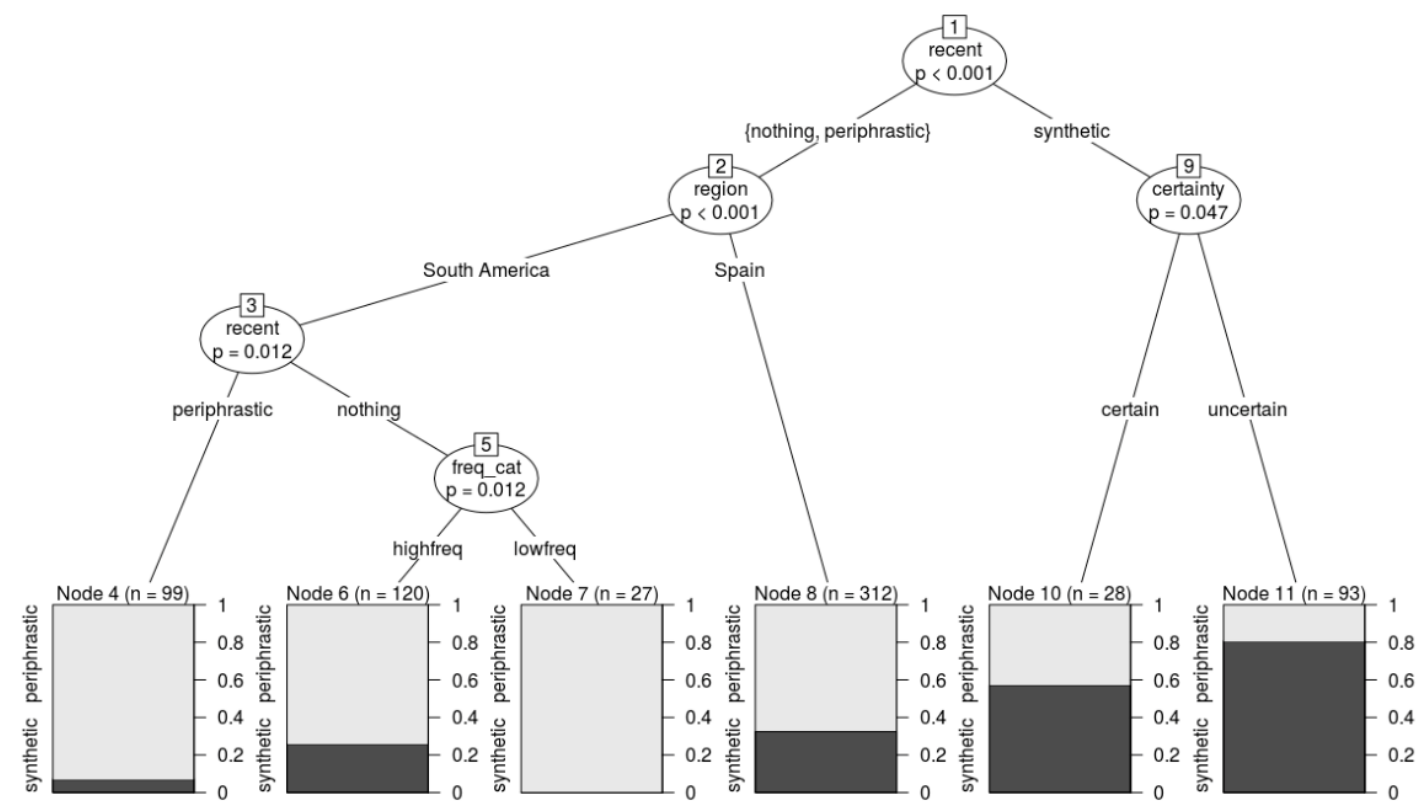

FIGURE 11 - Inference tree combining all factors

\section{Conclusion}

The aim of our research was to examine the weight of the priming effects in the variation between the synthetic and periphrastic future forms in Spanish. To our knowledge, this was the first work to look at priming effects regarding the selection of future expression forms in Spanish. Our results showed that a combination of linguistic factors contribute to the occurrence of the SF: priming effect; certainty; and verb frequency. These results are informative in the sense that they account for the interplay of variables that govern the variation between these two future forms.

We demonstrated that cognitive factors in combination with semantic ones should be taken into consideration when we talk about the variation between the SF and the PF in Spanish. Our study also provides evidence for the fact that the obsolescing construction - the synthetic form - will have a stronger priming effect in the larger process of language variation and change of future forms in 


\section{REVISTA DA ABRALIN}

Spanish. Our work offers an important addition to the literature about the effects of persistence and entrenchment in language. Our results also showed that speakers are sensitive to contextual activation and language-use factors. In conclusion, it is important that future studies about this and other related topics take into consideration semantic, frequency and cognitive factors.

\section{REFERÊNCIAS}

AARON, J. E. A Certain Future: Epistemicity, Prediction, and Assertion in Iberian Spanish Future Expression. Studies in Hispanic and Lusophone Linguistics, v.4, n.2 p. 215-240, 2014. DOI: https://doi.org/10.1515/shll-20141166

ALMEIDA, M.; M. DÍAZ. Aspectos sociolingüísticos de un cambio gramatical: la expresión de futuro. Estudios Filológicos, v.33, p. 7-22, 1998. DOI: https://doi.org/10.4067/S0071-17131998003300001

BLAS ARROYO, J. L . 2008. The Variable Expression of Future Tense in Peninsular Spanish: The Present (and Future) of Inflectional Forms in the Spanish Spoken in a Bilingual Region. Language Variation and Change, v.20, n.1, p.85-126, 2008. DOI: https://doi.org/10.1017/S095439450800001X

DAVIES, M. A Frequency Dictionary of Spanish: Core Vocabulary for Learners. Routledge Frequency Dictionaries. New York ; London: Routledge, 2006.

FERNÁNDEZ RAMÍREZ, S. [1940-1950] Gramática española, 4. El verbo y la oración (comp de I. Bosque). Madrid: Arco/Libros, 1986.

FLEISCHMAN, S. The Future in Thought and Language. Diachronic Evidence from Romance. Cambridge: Cambridge University Press, 1982.

KANY, C. E. American-Spanish Syntax. Chicago: University of Chicago, 1945

LANGACKER, R. Foundations of Cognitive Grammar. Theoretical Prerequisites. Stanford: Stanford University Press, 1987.

LEECH, G., HUNDT, M., MAIR, C.; SMITH, N. Change in Contemporary English: A Grammatical Study. Cambridge: Cambridge University Press, 2009.

MEYER, E. D.; SCHVANEVELDT, W. R. Facilitation in recognising pairs of words: evidence of a dependence between retrieval operations. Journal of Experimental Psychology, v.90, n.2, p. 227-234, 1971.

MORENO FERNÁNDEZ, F., CESTERO MANCERA, A. M., MOLINA MARTOS, I; PAREDES GARCÍA, F. La lengua hablada en Alcalá de Henares: Corpus PRESEEA - Alcalá. I, Hablantes de Instrucción Superior. Alcalá de Henares: Universidad de Alcalá, 2002.

ROSEMEYER, M. How Usage Rescues the System: Persistence as Conservation. In: ADLI, A., GARCÍA, G. M; KAUFMANN, G. (Eds.). Variation in Language: System- and Usage-Based Approaches. Berlin \& New York: De Gruyter, 2015, p.289-311. 


\section{REVISTA DA ABRALIN}

ROSEMEYER, M.; SCHWENTER, S. A. Entrenchment and Persistence in Language Change: The Spanish Past Subjunctive. Corpus Linguistics and Linguistic Theory, v.15, n.1, p.167-204, 2019. DOI: https://doi.org/10.1515/cllt-2016-0047

SAMPER, J. A., HERNÁNDEZ CABRERA, C. E; TROYA, M. Macro-corpus de la norma lingüística culta de las principales ciudades del mundo hispánico. Canarias: Universidad de las Palmas, 1998.

SEDANO, M. El futuro morfológico y la expresión ir a + infinitivo en el español hablado de Venezuela. Verba, v.21, p.44-66, 1994.

SEDANO, M. Importancia de los datos cuantitativos en el estudio de las expresiones de futuro. Revista Signos, v.39, n.61, p.283-296, 2006. DOI: http://dx.doi.org/10.4067/S0718-09342006000200007

SZMRECSANYI, B. Language Users as Creatures of Habit: A Corpus-Based Analysis of Persistence in Spoken English. Corpus Linguistics and Linguistic Theory, v.1, n.1, p.113-149, 2005. DOI:

https://doi.org/10.1515/cllt.2005.1.1.113 